\title{
MENIMBANG MODEL PEMBELAJARAN (Kajian Teoretis-Kritis atas Model Pembelajaran dalam Pendidikan Islam)
}

\author{
Abas Asyafah \\ Universitas Pendidikan Indonesia (UPI), Indonesia \\ E-mail:abasasyafah@upi.edu
}

\begin{abstract}
This article examines the learning model. This study departs from the fact that there are some people who still need a reference to weigh a learning model. A common problem to be answered through this study is how to weigh a learning model. This study uses a descriptive method because the researcher is analyzing the current problem and uses a qualitative approach. Through library, the author concludes that a good learning model must be assessed in terms of validity, practical use, and effectiveness. In weighing a learning model, we must first understand the concepts / theories about the learning model as a whole. If there is still a gap between the theory and the model, it means that the learning model must be revised and developed again.
\end{abstract}

Keywords: Learning Model, Considering Learning Model, and Islamic Education

\begin{abstract}
Abstrak. Artikel ini mengkaji tentang model pembelajaran. Kajian ini berangkat dari fakta bahwa masih ada kalangan yang masih membutubkan suatu acuan untuk. menimbang suatu model pembelajaran. Masalah umum yang ingin dijawab melalui kajian ini adalah bagaimana cara menimbang suatu model pembelajaran?. Kajian ini menggunakan metode deskriptif karena peneliti sedang menganalisis permasalahan yang sedang terjadi saat ini dan menggunakan pendekatan kualitatif. Melalui studi kepustakaan (library research), penulis berkesimpulan babwa sebuah model pembelajaran yang baik harus dapat dinilai dari sisi validitas (kesabihan), kepraktisan/keterpakaian, dan efektivitasnya. Untuk menimbang sebuah model pembelajaran, kita terlebih dahulu harus memahami konsep/teori tentang model pembelajaran secara utub dan lengkap. Bila masib ditemukan kesenjangan antara teori dengan model tersebut berarti model pembelajaran tersebut masih harus direvisi dan dikembangkan lagi.
\end{abstract}

Kata Kunci: Model Pembelajaran, Menimbang Model Pembelajaran, dan Pendidikan Islam 


\section{PENDAHULUAN}

Model pembelajaran merupakan salah satu komponen penting dalam pembelajaran. Ada beberapa alasan pentingnya pengembangan model pembelajaran, yaitu: a) model pembelajaran yang efektif sangat membantu dalam proses pembelajaran sehingga tujuan pembelajaran lebih mudah tercapai, b) model pembelajaran dapat memberikan informasi yang berguna bagi peserta didik dalam proses pembelajarannya, c) variasi model pembelajaran dapat memberikan gairah belajar peserta didik, menghindari rasa bosan, dan akan berimplikasi pada minat serta motivasi peserta didik dalam mengikuti proses pembelajaran, d) mengembangkan ragam model pembelajaran sangat urgen karena adanya perbedaan karakteristik, kepribadian, kebiasaan-kebiasaan cara belajar para peserta didik, e) kemampuan dosen/guru dalam menggunakan model pembelajaran pun beragam, dan mereka tidak terpaku hanya pada model tertentu, dan f) tuntutan bagi dosen/guru profesional memiliki motivasi dan semangat pembaharuan dalam menjalankan tugas/profesinya.

Namun untuk mengembangkan, membuat, memilih, dan menggunakan suatu model pembelajaran, seorang guru/dosen/peneliti dihadapkan suatu tahap pengukuran, penilaian, dan mengevaluasi atau menimbang suatu model pembelajaran. Hal ini diharapkan dapat memberi jawaban atas permasalahan umum "apa dan bagaimana konsep model pembelajaran" dan instrumen apa saja yang dapat dipakai untuk menimbang suatu model pembelajaran? Sedangkan tujuan yang hendak dicapai adalah memperoleh jawaban atas permasalahan umum di atas serta masalah-masalah khusus yang mengikutinya. Jawaban atas permasalahan ini merupakan sebuah konsep tentang "model pembelajaran" yang selanjutnya dapat digunakan sebagai landasan untuk menimbang suatu model pembelajaran dan menentukan instrumen lainnya.

\section{METODE PENELITIAN}

Kajian ini menggunakan metode deskritif karena peneliti sedang menganalisis permasalahan yang sedang terjadi saatsaat ini, sedangkan pendekatannya menggunakan pendekatan kualitatif. Data diperoleh dengan book survey sehingga dapat menjawab permasalahan yang diajukan dalam penelitian.

Pengumpulan, pengolahan dan analisis data dilakukan sekaligus (serempak) karena merujuk pada tulisan Ali (2019, hal. 126), Creswell (2014, hal. 277) dan Miles \& Haberman (1994) bahwa analisis data terdiri dari tiga alur kegiatan yang terjadi secara bersamaan yaitu: (1) reduksi data, (2) display data, dan (3) penarikan kesimpulan/verifikasi. Ada-pun teknik yang digunakan adalahan teknik analisis komponensial (componential analysis).

Teknik ini digunakan untuk menganalisis unsur-unsur yang memiliki hubungan-hubungan yang kontras satu sama yang lain dalam domain-domain yang telah ditentukan untuk dianalisis secara lebih terperinci dengan urutan kegiatan (1) penggelaran hasil searching data dari referensi, (2) pemilihan hasil searching, dan (3) menemukan elemenelemen kontras dan penting yang dapat menjawab pertanyaan penelitian. Dengan metode dan prosedur penelitian ini, maka dapat disajikan hasil dan pembahasan penelitian sebagai berikut.

\section{HASIL PENELITIAN DAN PEMBAHASAN}

Untuk dapat menimbang suatu model pembelajaran, kita menghajatkan sebuah kajian konseptual bahkan teori tentang "model pembelajaran". Dalam Kamus Besar Bahasa Indonesia, Moeliono (1990, 
hal. 456) mengartikan "konsep sebagai ide ataupun pengertian yang diabstrakkan dari peristiwa kongkret". Sedangkan Waney (1989, hal. 68-70) mengungkapkan pula "makna konsep yaitu suatu istilah yang dipergunakan untuk mengelompokkan sejumlah objek, peristiwa atau proses yang mempunyai ciriciri sama". Berdasarkan dua pengertian tersebut, maka Asyafah (2014, hal. 2) menyatakan bahwa konsep itu dapat diartikan sebagai gambaran atau abstraksi tentang sejumlah fenomena baik objek, proses, atau apapun yang dibuat oleh seseorang (pembuat konsep) pada waktu tertentu dengan maksud membuat susunan, memberi makna atas pengalamannya, yang mempunyai ciri-ciri yang sama untuk memahami hal-hal lain. Selanjutnya Asyafah (2014, hal. 3) menjelaskan tingkat kompleksitas dari setiap konsep, sangat tergantung dari banyaknya pengalaman dalam penciptaan konsep tersebut. Setiap konsep mengandung dua dimensi, yaitu 1) suatu bentuk atau separangkat komponen isi, dan 2) struktur atau pola hubungan dari komponen yang satu dengan yang lainnya dan hubungan secara keseluruhan.

Pembahasan kita dalam tulisan ini merupakan upaya penelusuran penulis tentang konsep "Model Pembelajaran". Upaya ini diharapkan sebagai dasar untuk untuk dapat menimbang suatu model pembelajaran secara ilmiah. Keseluruhan konsep ini terdiri atas 1) pengertian model pembelajaran, 2) landasan-landasan model pembelajaran, 3) fungsi model pembelajaran, 4) unsurunsur model pembelajaran, 5) ciri-ciri model pembelajaran, 6) kriteria model pembelajaran, 7) jenis dan rumpun model pembelajaran, 8) Cara memilih model pembelajaran, 9) cara mengevaluasi model pembelajaran, 10) dampak dari model pembelajaran, dan 11) keunggulan dan keterbatasan model pembelajaran. Berikut ini uraian masingmasing secara berurutan.

\section{Pengertian}

Secara etimologis model berarti pola dari sesuatu yang akan dibuat atau dihasilkan. Model dapat dipandang dari tiga jenis kata yaitu: a) sebagai kata benda, b) kata sifat, dan c) kata kerja. Sebagai kata benda, model berarti representasi atau gambaran. Sebagai kata sifat model adalah ideal, contoh, dan teladan. Sebagai kata kerja model adalah memperagakan, memper-tunjukkan. Dalam penelitian pengembangan model itu dirancang sebagai suatu penggambaran operasi dari prosedur penelitian pengembangan secara ideal dengan tujuan untuk menjelaskan atau menunjukkan alur kerja dan hubunganhubungan penting yang terkait dengan penelitian.

Secara umum, model dipandang sebagai suatu representasi (baik visual maupun verbal) yang menyajikan sesuatu atau informasi yang kompleks, luas, panjang, dan lama menjadi sesuatu gambaran yang lebih sederhana atau mudah untuk dipahami. Dalam penelitian pengembangan model sengaja dibuat oleh peneliti sebagai bagian dari upaya pengembangan sesuai dengan paradigma yang dianut oleh peneliti. Bagi Dewey dalam Joice dan Weil (2000, hal. 13) dinyatakan bahwa "the core of teaching process of invironments within which the students can interact and study how to learn". Terkait dengan hal ini selanjutnya Joice \& Weil mengatakan bahwa "A model of teaching is a description of a learning environment". Sedangkan pengertian model pembelajaran berdasarkan Permendikbud Nomor 103 Tahun 2014 tentang "Pembelajaran adalah kerangka konseptual dan operasional pembelajaran yang memiliki nama, ciri, urutan logis, pengaturan, dan budaya" (Anonim, 2018, hal. 3). 
Isitilah-istilah model, pendekatan, strategi, metode, dan teknik merupakan istilah yang sangat familiar di lingkungan pendidikan, namun terkadang istilahistilah tersebut membuat bingung, selain itu para ahli juga memiliki makna yang berbeda-beda terhadap istilah-istilah tersebut. Pada beberapa referensi para ahli membuat pengertian tentang "model pembelajaran" yang apabila kita pelajari secara seksama akan ditemukan keragaman, namun jika ditarik benang merahnya, maka akan kita dapati esensi dari pemengertian-pengertian mereka itu. Bagi saya, yang dimaksud dengan model pembelajaran adalah sebuah deskripsi yang menggambarkan disain pembelajaran dari mulai perencanaan, proses pembelajaran, dan pasca pembelajaran yang dipilih dosen/guru serta segala atribut yang terkait yang digunakan baik secara langsung atau tidak langsung dalam disain pembelajaran tersebut. Berdasarkan pengertian ini, maka dalam suatu model pembelajaran diartikan sebagai suatu rancangan atau pola konseptual yang memiliki nama, sistematis dapat digunakan dalam menyusun kurikulum, memanaj materi, mengatur aktivitas peserta didik, memberi petunjuk bagi pengajar, mengatur setting pembelajaran, menciptakan lingkungan belajar yang mendukung, mengarahkan pada tujuan yang diharapkan, dan mengevaluasinya (mengukur, menilai, dan memberikan feedback). Suatu model pembelajaran, juga haruslah menggambarkan operasionalisasi dari konsep di atas yang mengungkapkan berbagai realitas yang sesuai dengan situasi kelas dan macam pandangan hidup yang dihasilkan dari suatu kajian ekploratif.

Derdasarkan deskripsi di atas, dapat diikhtisarkan bahwa model pembelajaran itu merupakan suatu disain konseptual dan operasional pembelajaran yang memiliki nama, ciri, urutan logis, pengaturandan fasilitas yang relevan dengan kebutuhandalam pembelajaran. Pengertian model pembelajaran ini lebih luas cakupannya dari pendekatan, prosedur,strategi, metode, dan teknik pembelajaran. Dengan kata lain, model pembelajaran merupakan kerangka atau bungkus dari penerapan suatu pendekatan, prosedur,strategi, metode, dan teknik pembelajaran dari mulai perencanaan sampai pasca pembelajaran. Sekadar memberikan gambaran umum berikut ini dikemukanan pengertian dan contoh masing-masing. Pertama; Strategi pembelajaran merupakan separangkat kebijaksanaan yang dipilih oleh dosen/guru setelah dipertimbangkan faktor-faktor penentuan kebijakannya sehingga tercapai tujuan pembelajaran secara efektif dan efisien.Kedua; Pendekatan pembelajaran merupakan jalan atau arah yang ditempuh oleh gurusiswa dalam mencapai tujuan pembelajaran dilihat bagaimana materi itu disajikan (misalnya pendekatan induktif $><$ deduktif, teacher centered $><$ student centered.Ketiga; Metode pembelajaran merupakan cara mengajar secara umum yang dapat gunakan pada semua berbagai pelajaran, misalnya metode ceramah, ekspositori, tanya jawab. Keempat; Teknik mengajar merupakan penerapan secara spesifik suatu metode pembelajaran yang telah disesuaikan dengan berbagai aspek yang mempengaruhi pembelajaran, teknik jembatan keledai بَجْدِطَ (baca: bajuditoqo) merupakan teknik agar mudah mengingat huruf qolqolah).

\section{Landasan}

Kekokohan sesuatu bisa diukur dari landasan-landasan yang mendasarinya. Pertimbangan pentingnya landasan dalam mengembangkan suatu model pembelajaran adalah karena fungsi model pembelajaran yang sangat strategis dalam mencapai tujuan pembelajaran dan diperolehnya dampak positif darinya. Landasan-landasan yang dipandang 
penting dalam menimbang suatu model pembelajaran setidaknya meliputi: a) landasan filosofis, b) landasan teoretis, c) landasan psikologis-pedagogis, dan d) landasan sosiologis. Jika model itu dikembangkan dari nilai-nilai religious, hendaknya ditambah dengan e) landasan religious.

\section{Fungsi}

Adapun fungsi model pembelajaran adalah: a) Pedoman bagi para perancang pembelajaran dan para pengajar dalam merencanakan kegiatan pembelajaran. b) Pedoman bagi dosen/ guru dalam melaksanakan pembelajaran sehingga dosen/guru dapat menentukan langkah dan segala sesuatu yang dibutuhkan dalam pembelajaran tersebut. c) Memudahkan para dosen/ guru dalam membelajarkan para muridnya guna mencapai tujuan yang ditetapkannya. d) Membantu peserta didik memperoleh informasi, ide, ketrampilan, nilai-nilai, cara berfikir, dan belajar bagaimana belajar untuk mencapai tujuan pembelajaran.

\section{Unsur-unsur}

Menurut Joyce dan Weil (2000, hal. 14) bahwa unsur-unsur yang harus ada dalam suatu model pembelajaran ada empat unsur, yaitu: 1) Syntax, 2) The social system, 3) Principles of reactio, dan 4)Support system. Di samping empat unsur di atas dalam buku "Model-Model Pembelajaran" yang dikeluarkan oleh Direktorat Pembinaan SMA Kementrian Pendidikan dan Kebudayaan RI (2018, hal. 3)(2017) ditambah saru unsur lagi, yakni instructional dan nurturant effects.

Pertama; Sintaks (syntax). Ia merupakan langkah-langkah operasional pembelajaran yang menjelaskan pelaksanaannya secara nyata. Di dalamnya dimuat tahapan perbuatan/ kegiatan dosen/guru dan peserta didik. Secara implisit, di balik tahapan tersebut terdapat karakteristik lainnya dari sebuah model dan rasional yang membedakan antara model pembelajaran yang satu dengan model pembelajaran yang lainnya. Jadi sintaks masing-masing model pembelajaran memiliki karakteristik masing-masing. Langkah-langkah pembelajaran secara umum dapat merujuk pada model (generik) Gleser (Asyafah, 2016, hal. 85)yang terdiri atas empat langkah, yaitu Intruksional Objectives, Entering Behavior, dan Performance. Kedua; The social system.Yaknisuasana dan norma yang berlaku dalam pembelajaran. Dalam langkah ini ditunjukkan peran, aktivitas, dan hubungan dosen/guru dengan peserta didik serta lingkungan belajarnya. Dalam hal ini peran dosen/guru bisa bervariasi pada satu model dengan model lainnya. Pada satu model, guru berperan sebagai fasilitator namun pada model yang lain guru berperan sebagai sumber ilmu pengetahuan, sebagai pengarah, dan lain-lain. Ketiga; Principles of reaction. Prinsip reaksi yang menunjukkan bagaimana dosen/guru memperlakukan peserta didik dan bagaimana pula ia merespon terhadap apa yang dilakukan peserta didiknya. Keempat; Support system. Sistem pendukung yang menunjukkan segala sarana, bahan, dan alat yang dapat digunakan untuk mendukung keberhasilan menggunakan model tersebut. Kelima; Instructionaland nurturant effects. Dampak intruksional merupakan hasil belajar yang diperoleh secara langsung berdasarkan tujuan yang ditetapkan (instructional effects) dan hasil belajar di luar yang ditetapkan disebut dengan dampak penyerta (nurturant effects).

\section{Ciri-Ciri}

Model pembelajaran mempunyai empat ciri khusus yang tidak dimiliki oleh strategi, metode, atau prosedur. Dalam wikipedia.org dikemukakan ciriciri tersebut antara lain: a) Rasional 
teoretik yang logis, disusun oleh para pencipta atau pengembangnya. b) Landasan pemikiran tentang apa dan bagaimana siswa belajar (tujuan pembelajaran yang akan dicapai). c) Tingkah laku mengajar-pelajar yang diperlukan agar model tersebut dapat dilaksanakan dengan berhasil; d) Lingkungan belajar yang diperlukan agar tujuan pembelajaran itu dapat tercapai.

\section{Kriteria}

Suatu model pembelajaran dapat dikatakan baik jika memenuhi kriteria tertentu. Dalam wikipedia.org dikemukakan tiga kriteria, yaitu valid, praktis, dan efektif. Sahih (valid) adalah kesahihan suatu model pembelajaran dinilai dengan dua hal,yaitu: a) Apakah model pembelajaran yang didisain didasarkan pada rasionalitas dan teori yang kuat? b) Apakah terdapat konsistensi internalnya?. Praktis, merupakan aspek kepraktisannya dapat diuji dengan: a) Penilain para ahli dan para praktisi yang menyatakan bahwa model yang dikembangkan dapat diterapkan secara praktis, b) uji lapangan (implementasi model) yang menunjukkan bahwa apa yang dikembangkan tersebut dapat diterapkan. Efektif; Aspek efektivitas dapat diuji dengan: a) Penilaian para ahli dan praktisi berdasarkan pengalamannya menyatakan bahwa model tersebut efektif, b) Hasil uji (penelitian) empirik yang menunjukkan efektivitas model tersebut dalam mencapai hasil yang diharapkan.

\section{Jenis-Jenis dan Rumpun}

Setyosari (2013, hal. 228-239) menun-jukkan tiga model penelitian pengem-bangan, yaitu model konseptual, model prosedural, dan model sistematis. Pertama model konseptual merupakan model yang bersifat analitis yang menjelaskan komponen-komponen produk yang dikembangkan dan keterkaitan antar komponennya.
Karakteristik model memperlihatkan hubungan antarkonsep yang satu dengan yang lain, konsep-konsep itu tidak memperlihatkan urutan secara bertahap. Model ini bersifat konstruktivistik, artinya urutan bersifat terbuka, berulang dan fleksibel. Kedua model prosedural, yaitu deskriptif yang menggambarkan alur atau langkah-langkah prosedural yang harus diikuti untuk menghasilkan suatu produk tertentu. Karakteristik yang menonjol pada model ini berupa urutan langkah-langkah, yang diikuti secara bertahap dari langkah awal hingga langkah akhir. Ketigamodel sistematis, model ini menggambarkan sesuatu dalam hubungan yang teratur dan logis sehingga membentuk suatu sistem yang utuh, menyeluruh, terpadu, mampu menjelaskan rangkaian sebab akibat menyangkut obyeknya.

Sekaitan dengan model-model pembelajaran, sepanjang upaya penelusuran penulis, Joyce \& Weil yang pertama kali mengekslorasi dan mengklasifikasi model-model mengajar dan ditulis dengan judul buku "Models of Teaching". Lebih dari 40 tahun Joyce dan Weil (2000, hal. 13)terus-menerus menelusuri model-model tersebut dan mengklasifikasikannya menjadi empat rumpun model, yaitu: a)rumpun model interkasi sosial, b) rumpunmodel pemerosesan informasi, c) rumpunmodel personal - humanistik, dan d) rumpun model modifikasi tingkah laku.

\section{Pemilihan Model}

Oleh karena model-model pembelajaran itu banyak ragam atau jenisnya, dan tidak ada model pembelajaran yang cocok untuk segala situasi dan kondisi, serta suatu model yang digunakan dalam pembelajaran tertentu atau topik terntetu pasti memiliki beberapa keunggulan dan keterbatansannya, maka seringkali guru/ dosen/ peneliti mendapatkan kesulitan dalam memilih atau menentukan sebuah 
model pembelajaran yang tepat yang akan digunakan dalam pembelajaran. Di samping itu boleh jadi dalam penerapan model pembelajaran tidak berhasil, padahal saat uji coba implementasi model sangat berhasil. Hal ini terkait banyakvariabel yang harus diperhitungkan oleh dosen/ guru/ peneliti. Secara umum, hal-hal yang dapat dipertimbangkan dalam memilih menentukan model pembelajaran adalah kesesuaian antara "model pembelajaran" dengan hal-hal berikut.

a. Karakteristik tujuan (kompetensi) yang ditetapkan.

b. Indikator Pencapaian Kompetensi/ IPK yang dikembangkan.

c. Tujua-n pembelajaran yang spesifik dalam mengembangkan potensi dan kompetensi.

d. Kemampuan dosen/guru dalam menggunakan model pembelajaran yang dipilih.

e. Karakteristik dan modalitas peserta didik.

f. Lingkungan belajar dan sarana pendukung belajar lainnya.

g. Kesesuaian dengan pendekatan, metoda, strategi, dan teknik yang digunakan.

h. Tuntutan dimensi tertentu, misalnya untuk menyingkap sesuatu konsep.

i. Jenis penilaian hasil belajar yang akan digunakan.

\section{Evaluasi}

Untuk mengevaluasi (mengukur dan menilai) suatu model pembelajaran guna mengetahui kelayakannya, efektivitas, dan efesien-sinya dilakukan dengan beberapa cara, yaitu: (1) Penilaian para ahli/pakar terkait dengan "model hipotetik" yang dikembangkan dan harus berbasis pada teori-teori yang digunakan, (2) Melalui uji eksperimen dengan langkah-langkah (a) Melakukan prates sebelum pembelajaran dimulai untuk mengetahui konsisi awal, (b) Melakukan observasi dan penilaian proses yang meliputi setiap langkah yang dilakukan dosen/guru dan peserta didik, dan (c) Melakukan pascates sesudah pembelajaran berakhir yang berbasis pada tujuan pembelanaran. Pengukuran dan penilaian ini untuk mengevaluasi hasil pembelajaran. (3) Inventori pendapat, tanggapan, atau respons peserta didik terkait model pembelajaran yang dipilih dan digunakan dalam pembelajaran.Dalam hal ini peserta didik memberikan masukan sebagai refleksi terhadap kegiatan pembelajaran dan model pembelajaran yang digunakan.

\section{Dampak}

Ada dua kategori dampak, yaitu instructional effects dan nurturant effects. Dampak intruksional merupakan hasil belajar yang diperoleh secara langsung berdasarkan tujuan yang ditetapkan (instructional effects) dan hasil belajar di luar yang ditetapkan sebagai dampak penyerta/pengiring(nurturant

effects).Misalnya, pada pembelajaran dengan menggunakan teknik pembelajaran examples non examples dampak instruksionalnya adalah:1) siswa menjadi lebih aktif, 2) siswa berani mengemukakan pendapat atau gagasannya sendiri, 3) siswa aktif berdiskusi, 4) siswa dapat belajar dari pengamatan sendiri. Sedangkan dampak pengiringnya adalah: a) siswa mampu meningkatkan kerjasama secara kooperatif untuk materi yang ditugaskan, b) siswa memiliki sikap bertanggung jawab, c) siswa berusaha memahami materi dengan baik, dan d) meningkatkan kemampuan siswa dalam memecahkan masalah.

\section{Keunggulan dan Kelemahan}

Suatu model yang digunakan dalam pembelajaran tertentu atau topik terntetu pasti memiliki beberapa keunggulan dan keterbatansannya. Suatu disain model pembelajaran hendaknya secara definitif dijelaskan sisi-sisi keunggulan dan kelemahannya. Hal ini penting sebagai 
bahan pertimbangan bagi para dosen/guru peneliti dalam memilih dan menggunakan model tersebut.Untuk dapat mengungkap keunggulan dan keterbatansan sebuah model pembelajaran harus dilakukan uji emprik dari lapangan.

Dari hasil penelusuran (searching) beberapa referensi berhasil diperoleh sejumlah data, kemudian direduksi, didisplay dan diverifikasi maka diperolehlah hasil cara menimbang sebuah model pembelajaran. Untuk menimbang sebuah model pembelajaran dapat dilakukan dengan hal-hal sebagai berikut: (1) Penilaian pakar dan praktisi pendidikan, (2) Pengukuran efektivitas model pembelajaran, (3) Mengukur proses (implementasi) pembelajaran, (4) Mengukur tingkat keterpakaian model pembelajaran (5) Analisis disain faktorial,

(6) Teknik Forum Group Discutian (FGD).

\section{Penilaian Pakar dan Praktisi Pendidikan}

Untuk dapat menimbang suatu model pembelajaran antara lain dapat didisain dengan instrumen inventori tentang kelengkapan dan kualitas masing-masing unsur dari konsep/teori "Model Pembelajaran" sebagaimana telah disajikan secara padat di atas.

Berdasarkan hasil pengukuran dan penilaian pakar dan atau praktisi ini dengan teknik instrumen, penimbang dapat mengevaluasi suatu konsep model pembelajan tertentu. Lalu, kemampuan dan pengalaman para pakar dan para praktisi pendidikan dapat juga dimanfaatkan untuk menilai model tertentu terkait dengan keunggulanketerbatasan model pembelajaran serta dampak dari model tersebut dalam berbagai aspeknya. Untuk hal ini bisa dilakukan juga dengan teknik "curah pendapat" baik secara tertulis maupun secara lisan (wawancara).

\section{Mengukur Efektivitas Model Pembelajaran}

Untuk mengukur efektivitas suatu model pembelajaran dapat dilakukan dengan cara membandingkan kemampuan peserta didik sebelum pembelajaran dengan kemampuan mereka setelah pembelajaran. Oleh karena itu harus diketahui tingkat kesiapan belajar serta kondisi awal kemampuan peserta didik dapat dilakukan dengan tes (prates). Instrumennya diturunkan dari tujuan pembelajaran atau Capaian Pembelajaran Lulusan (CPL) yang telah dirumuskan dalam mendisain pembelajaran, yang meliputi kompetensi sikap, pengetahuan, dan keterampilan. Adapun konten atau materi pembelajarannya ditetapkan berdasarkan penggunaan model pembelajaran tersebut dalam pokok bahasan apa? Untuk mengetahui kemampuan peserta didik setelah proses pempelajaran dilakukan pascates. Instrumen tesnya sama dengan instrumen prates.

\section{Mengukur Proses (Implementasi) Pembelajaran}

Untuk mengevaluasi proses pembelajaran dapat dilakukan dengan teknik observasi partisipatif yang secara langsung dosen/guru yang bersangkutan melakukannya. Di itu dapat pula ditambah oleh observer lain (ahli/ praktisi pendidikan) dengan teknik observasi non partitipatif. Dengan banyaknya pengamatan akan meningkatkan reliabilitas data hasil pengamatan. Alat yang dapat digunakan berupa pedoman observasi tentang proses pembelajaran berdasarkan standar proses yang berlaku. Pedoman observasi harus sudah disiapkan sebelum pembelajaran. Hasil observasi merupakan bahan untuk merefleksikan tentang proses (implementasi) pembelajaran sehingga dapat tereksplorasi kebaikan-kebaikan model pembelajaran, kelemahan-kelemahan model pembelajaran, bahkan dampak intruksional dan dampak ikutannya. 


\section{Mengukur Tingkat Keterpakaian Model Pembelajaran}

Agar dapat mengetahui apakah suatu model pembelajaran terpakai atau tidak, dapat diketahui dari respons peserta didik disamping dari hasil pascates dan observasi proses pembelajaran sebagaimana telah dideskripsikan di atas.Di samping itu juga dapat diketahui dari respons praktisi pendidikan yang menguji coba model pembelajaran tersebut di kelas-kelas mereka secara terbatas. Adapun instrumen yang dapat dikembangkan antara lain berupa tes "skala diferensiasi semantik" yang modelnya disajikan berikut ini:

PENILAIAN PESERTA DIDIK TENTANG MODEL PEMBELAJARAN

Petunjuk:

$\Leftrightarrow$ Anda diminta untuk menilai model pembelajaran .... yang baru saja digunakan.

$\Leftrightarrow$ Berilah tanda $\sqrt{ }$ pada kolom yang disediakan.

$\stackrel{4}{4}$ Untuk penilaian sangat positif pilih angka 3, positif pilihlah angka 2 , agak positif pilihlah angka 1, dan angka 0 bila Anda ragu atau tidak berpendapat.

$\stackrel{4}{4}$ Untuk penilaian sangat negatif pilih angka 3 , negatif pilihlah angka 2 agak negatif pilihlah angka 1, dan angka 0 bila Anda ragu atau tidak berpendapat

$\rightarrow$ Bila Anda akan bemberi penilaian tambahan dapat mengisinya pada kolom yang masih kosong di bawah.

\begin{tabular}{|c|c|c|c|c|}
\hline \multirow{2}{*}{ Positif $\longrightarrow$} & \multicolumn{3}{|c|}{ PENILAIAN } & \multirow{2}{*}{$\longleftarrow$ Negatif } \\
\hline & \begin{tabular}{l|l|l|}
3 & 2 & 1 \\
\end{tabular} & & \begin{tabular}{|l|l|l|l}
1 & 2 & 3 \\
\end{tabular} & \\
\hline Menarik & & & & Membosankan \\
\hline Mudah diikuti & & & & \\
\hline Menyenangkan & & & & Menyebalkan \\
\hline Menggairahkan & & & & Menjenuhkan \\
\hline $\begin{array}{l}\text { Mepermudah pemahaman } \\
\text { materi }\end{array}$ & & & & Mempersulit pemahaman materi \\
\hline $\begin{array}{l}\text { muaden } \\
\text { sikap menapai kompetensi } \\
\text { sika }\end{array}$ & & & & Sulitmencapai kompetensi sikap \\
\hline $\begin{array}{l}\text { Mudah menapai kompetensi } \\
\text { pengetahuan }\end{array}$ & & & & $\begin{array}{l}\text { Sulit mencapai kompetensi } \\
\text { pengetahuan }\end{array}$ \\
\hline $\begin{array}{l}\text { Mudah menapai kompetensi } \\
\text { keterampilan }\end{array}$ & & & & $\begin{array}{r}\text { Sulit mencapai kompetensi } \\
\text { keterampilan }\end{array}$ \\
\hline $\begin{array}{l}\text { dik lebih aktif } \\
\text { a }\end{array}$ & & & & $\begin{array}{r}\text { Peserta didik lebih pasif } \\
\text { belajamya }\end{array}$ \\
\hline dik berani menge- & & & & $\begin{array}{l}\text { Peserta didik enggan me- } \\
\text { ngemukakan gagasannya }\end{array}$ \\
\hline $\begin{array}{l}\text { Peserta didik dapat belajar dari } \\
\text { temannya }\end{array}$ & & & & $\begin{array}{c}\text { Peserta didik hanya belajar dari } \\
\text { gurunya }\end{array}$ \\
\hline $\begin{array}{l}\text { Peserta didik dapat belajar } \\
\text { berkoopratif }\end{array}$ & & & & $\begin{array}{c}\text { Peserta didik belajaj secara } \\
\text { individual }\end{array}$ \\
\hline $\begin{array}{l}\text { Peserta didik memiliki motif } \\
\text { belajar tinggi }\end{array}$ & & & & $\begin{array}{l}\text { Peserta didik memiliki motif } \\
\text { belajar nya rendah }\end{array}$ \\
\hline $\begin{array}{l}\text { Dapatmemecahkan masalah } \\
\text { yang dihadapi }\end{array}$ & & & & $\begin{array}{l}\text { Sulit memecahkan masalah hang yang } \\
\text { dihadapi }\end{array}$ \\
\hline JUMLAH & & & & JUMLAH \\
\hline
\end{tabular}

Dari hasil penilaian peserta didik tersebut dapat dijadikan data untuk menimbang keterpakaian model pembelajaran, keunggulan-kelemahan model pembelajaran, dan dampak model pembelajaran.

\section{Analisis Disain Faktorial}

Disain faktorial merupakan solusi atas kelemahan disain eksperimen murni (true experimental), yaitu dengan memperhatikan kemungkinan adanya variabel moderator yang mempengaruhi perlakuan (variabel independen) terhadap hasil atau variabel dependen (Sugiyono, 2015, hal. 113), Sudjana dan dan Ibrahim (1989, hal. 48) menyatakan bahwa disain faktorial merupakan disain yang dapat memberikan perlakuan atau manipulasi dua variabel bebas atau lebih pada waktu yang bersamaan untuk melihat efek masing-masing variabel bebas, secara terpisah dan secara bersamaan terhadap variabel terikat dan efek-efek yang terjadi akibat adanya interaksi beberapa variabel. Pada umumnya peneliti melakukan manipulasi variabel bebas untuk melihat efeknya pada variabel terikat. Dalam praktiknya di lapangan pendidikan, perlakuan murni variabel bebas dan efeknya terhadap variabel terikat sulit dilaksanakan, sebab bagaimanapun juga ada variabel lain yang berinteraksi akibat kompleksnya kondisi eksperimen. Sujana dan Ibrahim (1989, hal. 48) memberi komentar bahwa dalam penelitian pendidikan tidak mungkin dapat memisahkan satu variabel dari variabel lain sebab dalam proses pendidikan banyak melibatkan interaksi antarmanusia dan manusia dengan lingkungan pendidikan.

Langkah awal agar dapat menganalisis data dengan menggunakan disain faktorial adalah memilih dan menentukan variabel lain di samping variabel independen dan dependen. Variabel-variabel lain yang dapat 
mengintervensi efektivitas perlakuan model pembelajaran tertentu terhadap hasil pembelajaran, misalnya kemampuan guru, suasana belajar, kedisiplinan peserta didik, kelengkapan alat dan media pembelajaran, durasi waktu, pengalaman belajar, jenis asal sekolah, jenis kelamin, usia, inteligensi, sosial ekonomi dan lain-lain. Variabel atribut tersebutdapat dibuat skala tertentu, misalnya status sosial ekonomi dikategorikan tinggi - sedang - kurang. Inteligensi dikategorikan tinggi-rendah, dan lain-lain. Variabel-variabel ini bagaimanapun bisa berpengaruh terhadap hasil pembelajaran, yang hasil analisis datanya dapat dipakai untuk menentukan kesimpulan penelitian tentang keunggulan-keterbatasan suatu model pembelajaran.

Ada dua kategori disain faktorial. Kategori pertama disain yang memanipulasi satu variabel bebas utama dengan mempertimbangkan variabel lain untuk dilihat efeknya pada variabel terikat. Kategori keduavariabel bebas utama diberikan perlakuan secara bersamaan dengan memperhitungkan variabel atribut untuk dilihat efek dari masing-masing variabel bebas utama, baik secara terpisah maupun secara bersama-sama, efek variabel atributnya, dan interaksi variabel bebas dengan variabel atribut pada variabel terikat.

1) Faktorial Kategori 1.

Disain kategori pertama digambarkan sebagai berikut:

\begin{tabular}{l|c|c|}
\hline Variabel Independen & \multicolumn{2}{|c|}{$\mathrm{X}$} \\
\hline Variabel Atribut & $\mathrm{Y}_{1}$ & $\mathrm{Y}_{2}$ \\
\hline Variabel Dependen & $\mathrm{O}_{1}$ & $\mathrm{O}_{2}$ \\
\hline
\end{tabular}

Keterangan:

$\mathrm{X}=$ Model Pembelajaran Tadabur Qurani

$\mathrm{Y}_{1}=$ Laki-laki

$\mathrm{Y}_{2}=$ Perempuan
Disain di atas dimaksudkan untuk menimbang efektivitas Model Pembelajaran Tadabur Qurani pada mahasiswa pada hasil pembelajaran. Subjek yang diteliti adalah mahasiswa semester tertentu yang terdiri atas dua kelompok, yakni kelompok laki-laki dan kelompok perempuan.Jumlah mahasiswa pada masing-masing kelompok harus sama, misalnya 30 orang. Pada disain ini peneliti memanipulasi satu variabel bebas utama (Tadabur Qurani) dengan mempertimbangkan variabel lain (jenis kelamin) untuk dilihat efeknya pada variabel terikat (hasil pembelajaran) baik pada kelompok laki-laki maupun pada kelompok perempuan. Hasilnya akan menujukan apakah efektivitas model tersebut karena perbedaan jenis kelamin atau bukan? Pada akhirnya bisa digunakan untuk analisis keunggulan atau kelemahan model tersebut dilihat dari jenis kelamin. Demikianlah selanjutnya dengan menggunakan variabel/atribut lain yang diduga dapat mempengaruhi hasil pembelajaran dengan menggunakan model pembelajaran manajemen informasi. Contoh lain paradigma disainfaktorial dapat digambarkan seperti berikut.

\begin{tabular}{|c|c|c|c|c|}
\hline Random & Prates & $\begin{array}{c}\text { Variabel } \\
\text { Independen }\end{array}$ & $\begin{array}{c}\text { Variabel } \\
\text { Moderator }\end{array}$ & $\begin{array}{c}\text { Variabel } \\
\text { Dependen }\end{array}$ \\
\hline $\mathrm{R}$ & $0_{1}$ & $\mathrm{X}$ & $\mathrm{Y} 1$ & $0_{2}$ \\
\hline $\mathrm{R}$ & $0_{3}$ & $\mathrm{X}$ & $\mathrm{Y} 1$ & $0_{4}$ \\
\hline $\mathrm{R}$ & $0_{5}$ & $\mathrm{X}$ & $\mathrm{Y} 2$ & $0_{6}$ \\
\hline $\mathrm{R}$ & $0_{7}$ & $\mathrm{X}$ & $\mathrm{Y} 2$ & $0_{8}$ \\
\hline
\end{tabular}

Model pembelajaran X dicobakan pada kelompok eksperimen pertama dan kedua yang telah diberi prates $\left(0_{1}\right.$ dan $\mathrm{O}_{3}=$ kelompok laki-laki) dan kelompok eksperimen ketiga dan keempat yang telah diberi prates $\left(0_{5}\right.$ dan $\mathrm{O}_{7}=$ kelompok perempuan). Pengaruh perlakuan X (Tadabur Qurani) terhadap kepuasan mahasiswa untuk kelompok laki-laki $=\left(0_{2}-0_{1}\right)-\left(0_{4}-0_{3}\right)$. Pengaruh perlakuan (MSI) terhadap kepuasan perkuliahan PAI untuk kelompok perempuan $=\left(0_{6}-0_{5}\right)-\left(0_{8}-0_{7}\right)$. 
Bila terdapat perbedaan pengaruh model pembelajaran baru $(\mathrm{X})$ terhadap kepuasan mahasiswa antara kelompok pria dan wanita, maka penyebab utamanya adalah bukan karena treatment yang diberikan (karena treatment yang diberikan sama), tetapi karena adanya variabel moderator, yang dalam hal ini adalah jenis kelamin, Pria dan wanita menggunakan model pembelajaran $\mathrm{X}$ yang sama, tempat pembelajaran diusahakan sama nyamannya, luasnya dll. tetapi pada umumnya, kelompok wanita lebih ramah lebih halus dalam berkomunikasi, sehingga dapat meningkatkan kepuasan bagi mereka (mahasiswa).

2) Faktorial Kategori 2

Disain kategori 2 digambarkan sebagai berikut:

\begin{tabular}{|l|c|c|c|c|}
\hline Variabel Independen & \multicolumn{2}{|c|}{$\mathrm{X}_{1}$} & \multicolumn{2}{c|}{$\mathrm{X}_{2}$} \\
\hline Variabel Atribut & $\mathrm{Y}_{1}$ & $\mathrm{Y}_{2}$ & $\mathrm{Y}_{1}$ & $\mathrm{Y}_{2}$ \\
\hline Variabel Dependen & $\mathrm{O}_{1}$ & $\mathrm{O}_{2}$ & $\mathrm{O}_{5}$ & $\mathrm{O}_{4}$ \\
\hline Hasil pascates & 70 & 66 & 80 & 60 \\
\hline
\end{tabular}

Keterangan:

$\mathrm{X}_{1}=$ Tadabur Qurani (misal)

$\mathrm{X}_{2}=$ Tadzkirah (misal)

$\mathrm{Y}_{1}=$ Laki-lakiI

$\mathrm{Y}_{2}=$ Perempuan

$\mathrm{O}_{1}, \mathrm{O}_{2}, \mathrm{O}_{3}$, dan $\mathrm{O}_{4}=$ Hasil belajar masing-masing

Pada disain faktorial kategori 2 ini ada dua variabel bebas utama yang dimanipulasi (diberikan perlakuan) misalnya Tadabur Qurani $\left(\mathrm{X}_{1}\right)$ dan model pembelajaran lain misalnya model pembelajaran Tadzkirab $\left(\mathrm{X}_{2}\right)$ secara bersamaan dengan memperhitungkan variabel atribut jenis kelamin $\left(\mathrm{Y}_{1}=\right.$ lakilaki dan $\mathrm{Y}_{2}=$ perempuan). Peneliti hendak melihat efek dari masing-masing variabel bebas utama $\left(\mathrm{X}_{1}\right.$ dan $\left.\mathrm{X}_{2}\right)$, baik secara terpisah maupun secara bersamasama tentang efek variabel atributnya $\left(Y_{1}\right.$ dan $\left.Y_{2}\right)$, dan interaksi variabel bebas $\left(\mathrm{X}_{1}\right.$ dan $\left.\mathrm{X}_{2}\right)$ dengan variabel atribut $\left(\mathrm{Y}_{1}\right.$ dan $\left.\mathrm{Y}_{2}\right)$, pada variabel terikat $\left(\mathrm{O}_{1}, \mathrm{O}_{2}, \mathrm{O}_{3}\right.$, dan $\mathrm{O}_{4}$.

Mencermati gambaran di atas, variabel atribut lebih berfungsi sebagai variabel kontrol. Disain ini dapat melihat dan menganalisis efek utama kedua jenis variabel bebas dan interaksi antara perlakuan variabel bebas.Disain faktorial seperti ini disebut disain faktorial sederhana dua kali atau $2 \times 2$, sebab mengandung dua variabel bebas yang masing-masing variabel bebas mempunyai dua kategori atau dua nilai. Dua variabel yang dimanipulasi berfungsi sebagai variabel eksperimen dan dua variabel bebas lainnya berfungsisebagai variabel kontrol. Efek pada variabel terikat dari variabel eksperimen dinilai pada setiap variabel kontrol.

Dari disain dan contoh hasil observasi atau pascates di atas dapat dijelaskan sebagai berikut:

1. Efek utama variabel bebas yang dimanipulasi, yakni $\left(\mathrm{X}_{1}\right)$ dan $\left(\mathrm{X}_{2}\right)$ pada hasil belajar. Skor rata-rata hasil belajar dari kedua perlakuan tanpa mempertimbangkan perbedaan jenis kelamin untuk sebagai berikut:

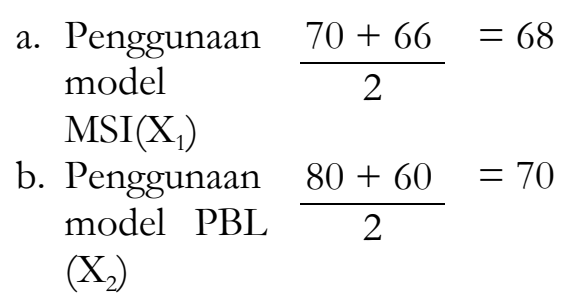

Perbedaan skor dari kedua metode pengajaran di atas, yakni $70-68=2$. Secara sederhana ada perbedaan antara efek dari kedua model pembelajaran tersebut, model $\operatorname{MSI}\left(\mathrm{X}_{1}\right)$ lebih efektif dibanding model PBL $\left(\mathrm{X}_{2}\right)$. Artinya, ada efek dari model pembelajaran pada hasil belajar.

b. Efek dari perbedaan jenis kelamin pada hasil belajar tanpa memperhitungkan perlakuan, yakni rata-rata skor hasil belajar untuk 
mahasiswa laki-laki dan rata-rata skor hasil belajar pada mahasiswi (perempuan) sebagai berikut:
c. Mahasiswa
$\frac{70+80}{2}=75$
d. Mahasiswi
$\left(\mathrm{Y}_{2}\right)$

$$
\frac{60+66}{2}=63
$$

Secara sederhana, hasil perhitungan di atas menunjukkan bahwa ada efek dari perbedaan jenis kelamin pada hasil pembelajaran terlihat jelas perbedaannya $(75-63=12)$, yang berarti mahasiswa lebih efektif daripada mahasiswi.

c. Efek interaksi antara kedua variabel bebas, yakni efek-efek yang berbeda dari salah satu variabel model pembelajaran pada perbedaan jenis kelamin. Jika ada interaksi efek perlakuan medelpembelajaran pada hasil belajar pada kedua jenis kelamin akan berbeda. Sebaliknya dikatakan tidak ada interaksi jika efek perlakuan medelpembelajaran pada hasil belajar pada kedua jenis kelaminakan sama. Dari rerata skor hasil belajar di atas, $\mathrm{X}_{1}$ lebih efektif bagi mahasiswa sebab skor $80>70$, sedangkan $\mathrm{X}_{2}$ lebih efektif bagi mahasiswi sebab $66>60$. Ini berarti pasangan perlakuan model pembelajaran tertentu dengan perbedaan jenis kelamin menunjukkan hasil yang berbeda dengan pasangan perlakuan model pembelajaran lain dengan perbedaan jenis kelamin lainnya. Jadi, ada efek interaksi antara model pembelajaran dengan perbedaan jenis kelamin. Data interaksi tersebut jika divisualkan adalah sebagai berikut:

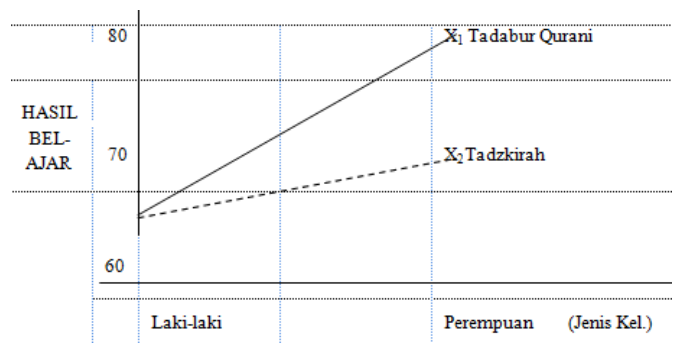

Grafik di atas menggambarkan efektivitas model pembelajaran bergantung kepada perbedaan jenis kelamin. Satu modelpembelajaran $\left(\mathrm{X}_{1}\right)$ lebih efektif pada satu taraf jenis kelamin $\left(\mathrm{Y}_{1}\right)$, dan satu modelpembelajaran lain $\left(\mathrm{X}_{2}\right)$ lebih efektif pada jenis kelamin yang lain $\left(\mathrm{Y}_{2}\right)$. Ini menunjukkan bahwa terdapat interaksi kedua variabel di atas (model pembelajaran dengan perbedaan jenis kelamin).

\section{Teknik FGD}

Istilah Focus Group Discation (FGD) saat ini sangat mashur dan banyak digunakan sebagai teknik pengumpulan data. FGD adalah diskusi yang dilaksanakan oleh peneliti dalam kelompok khusus untuk mengumpulkan informasi atau data dari beragam sudut pandang yang dilakukan secara bersama dalam suatu waktu dan tempat untuk memecahkan masalah penelitian sesuai dengan topik yang dibahasnya.

Ada beberapa tujuan dan kepentingan FGD, antara lain: a) peneliti membutuhkan pemahaman dari berbagai sudut pandang dan lebih bervariasi dalam waktu dan tempat yang bersamaan, b) peneliti membutuhkan informasi tambahan, c)sebagai bahan untuk mengeksplor lebih dalam lagi, c) untuk menyingkap fakta lebih detail dan kaya, d) untuk keperluan verifikasi data hasil temuan di lapangan, dan e) peneliti memperoleh kepuasan dan nilai akurasi yang tinggi.

Dalam pandangan Awaludin (2011, hal. 2) teknik FGD memiliki kelebihankelebihan: a) memberikan kemudahan dan peluang untuk menjalin keterbukaan kepada publik tentang penelitiannya, b) membangun keperca-yaan diri karena hasil penelitiannya sudah didiskusikan secara intensif dan mendapatkan masukan yang berharga, c) dapat mengetahui dan memahami persepsi dan sikap kelompok dalam FGD tentang 
temuan sementara dan gagasan peneliti, d) mendapatkan data dari pengalaman para informan serta memungkinkan peneliti dan informan berdiskusi secara intensif dan tidak kaku dalam membahas isu-isu yang sangat spesifik, e) memungkinkan peneliti mengumpulkan informasi penting secara cepat, konstruktif dari peserta yang memiliki latar belakang berbeda-beda, d) dinamika kelompok memberikan informasi yang penting, menarik, bahkan kadang tidak terduga, e) alat untuk meyakinkan peneliti sekaligus alat re-check terhadap berbagai keterangan/ informasi. Sedangkan keterbatasannya, antara lain bahwa hasil dari kegiatan FGD ini tidak dapat dipakai untuk melakukan generalisasi.

Adapun prosedur FGD meliputi tahap persiapan, pelaksanaan, dan pelaporan. Perencanaan matang diperlukan beberapa persiapan, misalnya membentuk tim, memilih tempat dan mengaturnya, menyiapkan logistik, menentukan peserta dapat memberikan kontribusi maksimal.

Peran moderator yang berfungsi strategis sebagai fasilitator dan memimpin jalannya diskusi sebaiknya peneliti sendiri, karena dialah yang paling memahami permasalahan penelitian. Notulen berperan strategis dalam merekam dan mengolah data. Dalam merekrut peserta mesti diperhatikan derajat homogenitas atau heterogenitas yang harus sesuai dengan tujuan awal FGD. Hal yang tak kalah pentingnya adalah menyusun dan membuat panduan diskusi yang terarah. Moderator sebaiknya menyusun pertanyaanpertanyaan kunci dengan ramburambunya disusun sebagai berikut: a) pahami tujuan penelitian serta data apa yang dibutuhkan, b) pahami tujuan FGD, c) pahami jenis informasi yang ingin didapatkan, d) bagaimana menggunakan dan mengolah informasi yang diperoleh dari FGD, dan e) buat pertanyaan umum/khusus yang efektif dan strategis.

Dalam pelaksanaan FGD, moderator memegang peran penting karena bertugas dalam a) membuka FGD dan mengkondisikan situasi, b) meminta klarifikasi, c) melakukan refleksi, d) memotivasi peserta FGD untuk memberikan kontribusinya, e) memprobing (penggalian lebih dalam), f) melakukan blocking dan distribusi, g) mereframing, h) me-refocusing, i) merilai perdebatan yang tidak kondusif dan tidak produktif, j) memanfaatkan jeda (pause) jika dibutuhkan, k) mengatur materi dan waktu berbicara, dan l) membuat kesimpulan dan menutup FGD.

Dalam mengolah data, kategorisasikan ragam pendapat yang muncul: a) konsensus atau kesepatatan, b) perbedaan pendapat, mungkin bersebrangan atau pertentangan, c) pengalaman yang berbeda atau pemahaman yang berbeda, d) ide-ide inovatif yang muncul, dan sebagainya, dan e) saran/kritik. Setelah klasifikasi lalu buat coding (pengkodean), lalu lanjutkan pada langkah-langkah menganalisis data dan terakhir buatlah laporan sebagai salah satu instrumen untuk menimbang suatu model pembelajaran.

\section{KESIMPULAN}

Kualitas suatu model pembelajaran dapat dinilai dari validitas (kesahihan), kepraktisan/keterpakaian, dan efektivitasnya. Untuk dapat menimbang sebuah model pembelajaran, dosen/ guru/ peneleliti harus terlebih dahulu memahami konsep/teori tentang model pembelajaran secara utuh dan lengkap. Berdasarkan konsep/teori tersebut penimbang dapat memperoleh standar ideal sebuah model dan membandingkannya dengan model yang sedang ditimbangnya. 
Bila masih ditemukan kesenjangan antara teoretis dengan model tersebut berarti model pembelajaran tersebut masih harus direvisi dan dikembangkan lagi. Kualitas suatu model pembelajaran di samping adanya kesesuaian dengan konsep/teori yang mendasarinya, dapat ditimbang dengan instrumen: a) penilaian pakar dan praktisi pendidikan, b) pengukuran efektivitas model pembelajaran, c) pengukuran proses pembelajaran (implementasi model), d) pengukuran tingkat keterpakaian model pembelajaran, e) analisis disain faktorial, dan f) hasil diskusi terfokus (FGD).

\section{REFERENSI}

Ali, M. (2019). Research Methods in Sustainability Education. Bandung: UPI Press.

Anonim. (2018). Model-Model Pembelajaran. Jakarta: Direktorat Pembinaan SMA Kementrian Pendidikan dan Kebudayan RI.

Asyafah, A. (2014). Konsep Tadabur AlQuran. Bandung: Maulana Media Grafika.

Asyafah, A. (2016). Metode Tadabur Qurani dalam Pembelajaran PAI. Bandung: Maulana Media Grafika.

Awaludin, I. (2011, Maret 28). https:/ / bincangmedia.wordpress.com. Dipetik April Selasa, 2018, dari https://bincangmedia.wordpress. com:

https://bincangmedia.wordpress. com

Bruce Joyce, M. W. (2000). Models of Teaching. Boston: Allyn and Bacon.

Creswell, J. W. (2014). Research Design; Pendekatan Kualitatif, Kuantitatif, dan Mixed. (A. Fawaid, Penerj.) Yogyakarta: Pustaka Pelajar.
Miles and Haberman. (1994). Qualitative Data Analysis Data Kualitatif. Oaks: Sage Publication.

Moeliono, A. M. (1990). Kamus Besar Bahasa Indonesia. Jakarta: Balai Pustaka.

Nana Sujana, Ibrahim. (1989). Penelitian dan Penilaian Pendidikan. Bandung: Sinar Baru.

Setyosari, P. (2013). Metode Penelitian Pendidikan dan Pengembangan. Jakarta: Kencana Prenadamedia Group.

Sugiyono. (2015). Metode Penelitian Kuantitatif, Kualitatif, dan R\&D. Bandung: Alfabeta.

Waney, M. H. (1989). Wawasan Ilmu Pengetahuan Sosial. Jakarta: P2LPTK Dikti, Depdikbud. 